\title{
HOW IS CURRENT PHARMACEUTICALS PRICING POLICY ON GENERICS PERFORMING IN TURKEY REGARDING PRICE EROSION?
}

\author{
Kadir GÜRSOY \\ Sosyal Güvenlik Uzmanı, Sosyal Güvenlik Kurumu, \\ e-posta:kgursoy@sgk.gov.tr, tel: 03124588018
}

Başvuru Tarihi: 05.10.2016, Kabul Tarihi: 25.01.2017

DOI: $10.21441 /$ sguz.2017.55

\begin{abstract}
Generics are commonly accepted to contribute significantly to treating disease by improving the affordability of pharmaceuticals. Once the patent expires for an originator brand, generics erode prices through creating fierce competition. The objective of this study is to investigate on Turkish pharmaceutical policies over generics through measuring how much they lower the prices, and then develop alternative strategies to maintain higher level of price reduction, and hence saving. Claims data from Turkish Social Security Institution (SSI) for all ambulatory care drugs reimbursed were collected monthly in the period of January 2009 to December 2013 and for selected 12 equivalent groups price erosion and saving impacts due to generic entry be computed. Moreover, the price erosion for 15 generics entering the reimbursement list in 2012 as first generics was measured. For 12 equivalent groups constituting nearly $7 \%$ of SSI drug spending, the price erosion was nearly $41 \%$ ranging from $8 \%$ to $74 \%$. In the first year of the first generic entry, on average the prices were only shrank by $39 \%$ with an increase of $41 \%$ in units sold. As a result of those analyses, it is concluded that Turkey is not maximizing its full potential with respect to generic medicines. Therefore, it is of great importance that policies such as therapeutic equivalence, tendering, and aggressive generic pricing policy to stimulate higher savings need to be introduced in the near future.
\end{abstract}

Keywords: Generic drugs, price erosion, saving impact, drug pricing policy, Turkey 


\section{FIYYATLARI DÜŞÜRME AÇISINDAN TÜRKIYE'DEKİ JENERIK İLAÇ FIYYTLAMA POLITTIKASININ PERFORMANS DEĞERLENDİRMESİ}

\section{$\ddot{O Z Z}$}

Jenerik ilaçlar, ilaçların maliyetini aşağ çekerek hastalıkların daha ucuz ilaçlarla tedavi edilmesine büyük katkı sağlamaktadır. Orijinal bir ilacın patent süresinin dolması ile birlikte, jenerikler piyasaya girerek rekabet yaratıp fiyatları düşürmektedir. Bu çalışma, Türkiye'deki jenerik ilaç politikalarının ilaç fiyatlarını aşağı çekme konusunda ne kadar başarılı olduğunu ölçmeyi ve hem daha çok tasarruf sağlamak hem de fiyatları daha da aşağı indirmek için alternatif stratejiler geliştirmeyi amaçlamaktadır. 2009 Ocak ile 2013 Aralık ayları arasındaki Sosyal Güvenlik Kurumu (SGK) üzerinden ayaktan alınan tüm ilaçların aylık verileri MEDULA sisteminden derlenmiş ve seçilmiş 12 farklı eşdeğer grubunun jenerik ilaçların ilgili gruplara girmesinin sağladığ tasarruf bulunmuştur. Ayrıca, 2012 yılında ilk jenerik olarak geri ödemeye giren 15 jenerik ilacın fiyatları ne kadar düşürdüğü ölçülmüştür. SGK ilaç bütçesinin yaklaşık \%7'sini oluşturan 12 eşdeğer grupta, jeneriklerin gruplarda bulunması fiyatları yaklaşı \% $\% 1$ düşmüştür, \%8 ile \%74 arasında tasarruf sağlanmıştır. Geri ödemeye giren 15 ilk jenerik ürünün, ilk yıl için sağladığ 1 tasarruf ortalama \%39 iken, bu ilaçların bulunduğu eşdeğer gruplarında kutu satışları \%41 artmıştır. Bu analizler sonucunda, jenerik ilaçların fiyatları daha da aşağı çekmesi bağlamında, Türkiye için hala politika alanının mevcut olduğu sonucuna varılmıştır. $\mathrm{Bu}$ yüzden, daha fazla tasarruf sağlamaya yönelik; terapötik eşdeğerlik, ihale ve rekabeti artırıcı ve fiyatları daha da aşağı çeken saldırgan jenerik politikaları gibi uygulamaların yakın bir gelecekte hayata geçirilmesi önem arz etmektedir.

Anahtar Kelimeler: Jenerik ilaçlar, fiyat erozyonu, tasarruf etkisi, ilaç fiyatlama politikası, Türkiye 


\section{INTRODUCTION}

Generic medicines are clinically used as a substitute in place of original brand medicines and provide the same quality, efficacy, and safety profiles (World Health Organization (WHO), 1988; US Food and Drug Administration (FDA), 2015; Cameron et al., 2009; Cameron et al., 2012; Sheppard, 2010). They are commonly accepted to contribute significantly to treating disease by improving the accessibility and affordability of pharmaceuticals (Cameron et al., 2009; Cameron et al., 2012; Sheppard, 2010; WHO, 1988). Once the patent expires for an originator brand, generics erode prices through creating fierce competition in the market, but how much price reduction it will end up depends on the policies implemented in each country.

In the last three decade, many governments and third party payers have been adopting policies to encourage utilization of generics in order to bend the pharmaceutical cost curve and create room for innovative and high-cost drugs further improving health status (Simoens and De Coster, 2006; Sermet et al., 2010; Godman et al., 2010; Godman et al., 2012; Vogler, 2012; Simoens, 2012; Seeley and Kanavos, 2008). Based on European Generic Medicines Association estimate, generics in European Union (EU) is generating a saving of $€ 30$ billion each year. In France, additional saving of at least $€ 1.5$ billion per year was seen from increased use of generics (Sermet et al., 2010). Based on Generic Pharmaceutical Association's report (2015), nearly 3.8 billion of the total 4.3 billion prescriptions dispensed in the US in 2014 were filled using generic drugs, accounting for nearly nine out of every $10(88 \%)$ prescriptions dispensed in the US and generic drugs were responsible for $\$ 254$ billion in health system savings in 2014, bringing the total savings over the last 10 years to $\$ 1.68$ trillion. The utilization of generic medicines within the unprotected market ranges between 24\% (Japan) to $89 \%$ (US), 51\% in Turkey (Sheppard, 2010). There has been an increasing trend in the market share of generics by volume in EU (Simoens, 2013). In EU, generics constituted $50 \%$ of sales volume but only $18 \%$ sales value (Sheppard, 2010).

Turkey has a strong branded generics market with domestic production. In 2013 generics represented $47 \%$ of sales volume and $31 \%$ of value, reducing 2 percentage points in volume and 4 points in value compared to 2009 . Relative to other EU countries the share of generics in value for Turkey is fairly higher, questioning whether they are eroding prices significantly. It seems that Turkey is not maximizing its full potential with respect to generic medicines.

The objective of this study is to investigate on Turkish pharmaceutical policies over generics through measuring how much they lower the prices, and then 
develop alternative strategies to maintain more price reduction and hence saving. The study first summarizes what generic drugs are and clarifies the market authorization, pricing, and reimbursement process of generics in Turkey. Then, it explains the methodology used for the analysis and lists the main results. Finally it develops alternative policies for further price erosion.

\section{Background on Generics}

Definition of a generic drug may vary by country, and be influenced by not only medical practice but also regulatory requirements. WHO (1988) defines generic drug as "a pharmaceutical product, usually intended to be interchangeable with an innovator product that is manufactured without a license from the innovator company and marketed after the expiry date of the patent or other exclusive rights". According to FDA (2015), a generic drug is a pharmaceutical drug that is proven to be equivalent to a brand-name drug in dosage, strength, route of administration, quality, performance, and intended use. The term may also refer to a drug marketed under its chemical name without advertising or to the chemical makeup of a drug rather than the brand name under which the drug is sold. Generic drugs may look or taste different from brand name drugs, but have the same chemical composition as their counterparts. This makes them identical in efficacy, potency, route of administration, strength and dosage (FDA, 2015; WHO, 1997; WHO, 1998; Tootelian et al., 1988).

First, a generic drug is designed to work the same way in the body as the original brand-name drug, providing the same quality compared to the brand-name drug. Second, generic drugs have the same active ingredient, the chemical that makes the drug work, and that means they work the same way in the body as the brandname drug. Generic drugs must also have the same amount of active ingredient in the prescription. The non-medicinal ingredients, such as fillers and preservatives, may be different from brand-name products, but they are also regulated and subject to the same review process. Third, to receive a license to manufacture and sell drugs in the market, both brand-name companies and generic drug companies must follow the same good manufacturing practices guidelines, which ensure consistent production and quality standards. Forth, when a generic prescription drug has been reviewed and authorized for sale, it means the medicine is as safe and effective as the original brand-name drug and works the same way in the body. As the action and effect of generic drugs are similar to the brand name drugs sold by pharmaceutical companies, they often prove to be the better choice.

When a medicine is first developed, the pharmaceutical company discovering and marketing it holds a patent on its new drug. The patent usually lasts for 20 years, to give the originating company a chance to compensate its research investment. After 
the patent expires, a generic version of the drug may become available. Generics are marketed under the drug's chemical or generic name and meet the same quality and effectiveness standards as the original.

Generic drugs are significantly cheaper than their branded equivalents. Since generic drugs are not patented or advertised, the only cost involved is the manufacturing cost of the drugs. So, they can be sold at much lower prices and the manufacturers are able to easily garner a profit on their sales. Besides, close competition in the market for generic drugs creates lower prices. As most of the drugs are almost similar in their effects, which are widely available in generic forms, the sales go higher for the drugs which are more affordable.

\section{Market Authorization, Reimbursement, and Pricing on Generics in}

\section{Turkey}

In Turkey all new drugs including generics are granted market authorization soon after they are reviewed for safety, efficacy, and quality in line with the regulation entitled as Registration Regulation of Human Medicinal Products designed to provide a brief introduction to the requirements for licensing, importing, and introducing pharmaceutical products to the Turkish market and then approved and their prices are determined by Medicines and Medical Devices Agency (TITCK), a subordinate organ of Turkish Ministry of Health (MOH) (TITCK, 2005).

Pharmaceuticals cannot be launched on the market before obtaining a license to be granted by the TITCK. In order to obtain a license, real persons or legal entities resident in Turkey shall file an application to the TITCK by submitting the documents listed under the regulation. Then preliminary evaluation process starts. Upon completion of the preliminary evaluation period which can be a maximum of 90 days (including the time period granted to the applicant to complete the missing documents/ information in the application file); the applications shall be evaluated and concluded within 210 days. However, the applications pertaining to pharmaceutical products which are original in treatment or diagnosis, which are innovative or are required from a public health perspective to reduce public healthcare expenditures and to ensure rapid public access to the drug, shall be completed within a maximum of 180 days.

Reimbursement system in Turkey rests upon a positive list where pharmaceutical companies can apply for admission to reimbursement to SGK once market authorization is granted and reference price is set. Reimbursement decision is the responsibility of the inter-ministerial Reimbursement Commission (RC). For each drug, pharmaceutical companies submit a dossier to the Medical and Economic Appraisal Committee (MEAC) containing general information, clinical data and literature review, and a pharmacoeconomic evaluation (shows the new treatment 
is cost-effective in comparison with alternative treatments) of the drug (SGK, 2016a). MEAC assesses all dossiers and declares its decision to RC and then RC finalizes the decision. Generics do not need to submit cost-effectiveness analysis if the comparator originator drug is in the reimbursement list. Instead, they have to provide a unit price comparison against innovator and other equivalent generic drugs. Furthermore, if the generic is asking for being in the positive list without the evaluation term, an extra minimum 5\% discount from the cheapest generic drug in the market is required (SGK, 2016a).

Turkey has a two-tier pricing system: international external reference pricing system based on ex-factory prices, and the reimbursement pricing system relying on differentiated public rebates applied to retail price. Under the Decree on the Pricing of Medicinal Products for Human Use, the reference price of a drug is determined according to the lowest ex-factory price among $5 \mathrm{EU}$ member countries, namely France, Spain, Italy, Portugal, and Greece (MOH, 2015). Generic prices are determined as $60 \%$ of the price of the originator product and cannot be higher than the originators' reference prices. Originators with generics are also priced at $60 \%$ of their lowest reference price. 20 year old product is a unique category present only in Turkish market defined as products whose any form are marketed before 1987 in any country (MOH, 2015). The price of 20 year old drugs is determined as $80 \%$ of the reference price if they have references. If the drug's ex-factory price is lower than $6.79 \mathrm{TL}$ then their reference price is $100 \%(\mathrm{MOH}, 2015)$.

Once the ex-factory price of the drug is determined, the price is converted into TL by using the fixed EUR/TRY exchange rate ${ }^{1}(2.1167)$ and then wholesale and pharmacy margins, plus a value-added tax of $8 \%$ are added to get the retail price. Then public rebate is deducted from that retail price. In addition, a pharmacy discount is applied on the price determined after the rebate. Public rebate is determined depending on the wholesaler's price and product group (SGK, 2016b). For example, all products having wholesale price lower than $3.83 \mathrm{TL}$ is exempted from that rebate. For generics, rebate is $10 \%(28 \%)$ if the wholesale price is between $3.83 \mathrm{TL}$ and 7.32 TL (more than $11.02 \mathrm{TL}$ ).

Turkey also applies molecule-based equivalent groups. Drugs whose active substance(s), pharmaceutical forms and unit amounts of raw material are the same form an equivalent group. For each equivalent group, the base price is calculated and up to $10 \%$ over the base price is reimbursed by SGK and the remaining is financed out-of-pocket (SGK, 2016b). However, a drug having the lowest price can only be accepted as a base-priced drug if it takes at least $1 \%$ sales volume of that group in one of last 5 months.

1 The currency of the reference price is Euro and a fixed EUR/TRY exchange rate, which is defined based on $70 \%$ of former year's average Euro foreign exchange sales rate realizations of the Central Bank of the Republic of Turkey, is used to convert the Euro prices to local currency (MOH, 2015). 
Table 1: Statutory rebates for reimbursed drugs at retail level as of February 23, 2016

\begin{tabular}{|c|c|c|c|c|}
\hline \multirow{2}{*}{ Product Group } & \multicolumn{4}{|c|}{ Regarding the sale price to wholesalers (in TL) } \\
\hline & Up to 3.83 & 3.83 to 7.32 & 7.33 to 11.02 & Above 11.02 \\
\hline Originators without Generics & $0.0 \%$ & $10.0 \%$ & $31.0 \%$ & $41.0 \%$ \\
\hline $\begin{array}{l}\text { Generics and Originators with } \\
\text { Generics }\end{array}$ & $0.0 \%$ & $10.0 \%$ & $18.0 \%$ & $28.0 \%$ \\
\hline \multicolumn{5}{|l|}{20 year-old products } \\
\hline Referenced & $0.0 \%$ & $0 \%$ & $10.0 \%$ & $28.0 \%$ \\
\hline Without Reference & $0.0 \%$ & $0 \%$ & $10.0 \%$ & $40.0 \%$ \\
\hline $\begin{array}{l}\text { Blood, Enteral nutrition products, } \\
\text { and medical formula }\end{array}$ & $0.0 \%$ & $11.0 \%$ & $11.0 \%$ & $11.0 \%$ \\
\hline
\end{tabular}

Source: SGK, 2016b

\section{Methods}

Claims data from Turkish SGK, for all ambulatory care drugs reimbursed were collected monthly in the period of January 2009 to December 2013. First, all ambulatory care drugs grouped into generics and originators and then the share of generic drugs both in terms of sales volume and value were calculated.

In addition, among nearly 1500 equivalent groups, 12 groups were selected. Those groups constituted the highest sales in value and in each group at least one originator drug was reimbursed. Then saving impact and price erosion for each group in 2013 were evaluated. Besides, evolution of generic share in volume and value were worked out and volume growth was also computed. Furthermore, weighted average discounted price were determined and compared with base price. To look at the impact of first generic entry, the price erosion and saving for 15 generics entering the reimbursement list in 2012 as first generics were measured in 2013 and volume growths were finalized. While measuring the price erosion, it was assumed that total sales units in each group stayed the same, all were met by originator drug/s, and the discounted public price was figured out as if there were no generics in the market. Price erosions under 6 six different wholesaler prices were also concluded.

Consequently, as alternative policy options, reducing the equivalent cap to the base price was assessed and saving impact was computed. Moreover, saving impact switching into therapeutic equivalence from molecule-based equivalence was analyzed for one ATC-3 group level. Finally, saving for reducing $60 \%$ of reference pricing for generics was found for selected 12 groups. 


\section{Results}

In Turkey, generics constituted $49 \%, 48 \%, 47 \%, 47 \%, 47 \%$ of all sales volume in 2009, 2010,2011, 2012, and 2013 respectively whereas they aggregated to $35 \%, 33 \%, 34 \%, 32 \%$, and $31 \%$ of all sales value respectively in the same years, indicating a slight reduction in both sales volume and value due to penetration of high-priced biologics. Compared to EU averages, generic share in Turkey regarding sales volume is close to EU figure (50\%). However, generics share in total sales value is fairly higher than EU average (18\%), arguing that there is still room for further price reduction in generics (Sheppard, 2010).

Figure 1: Generics and Originators Sales Volume in Turkey, 2009-2013

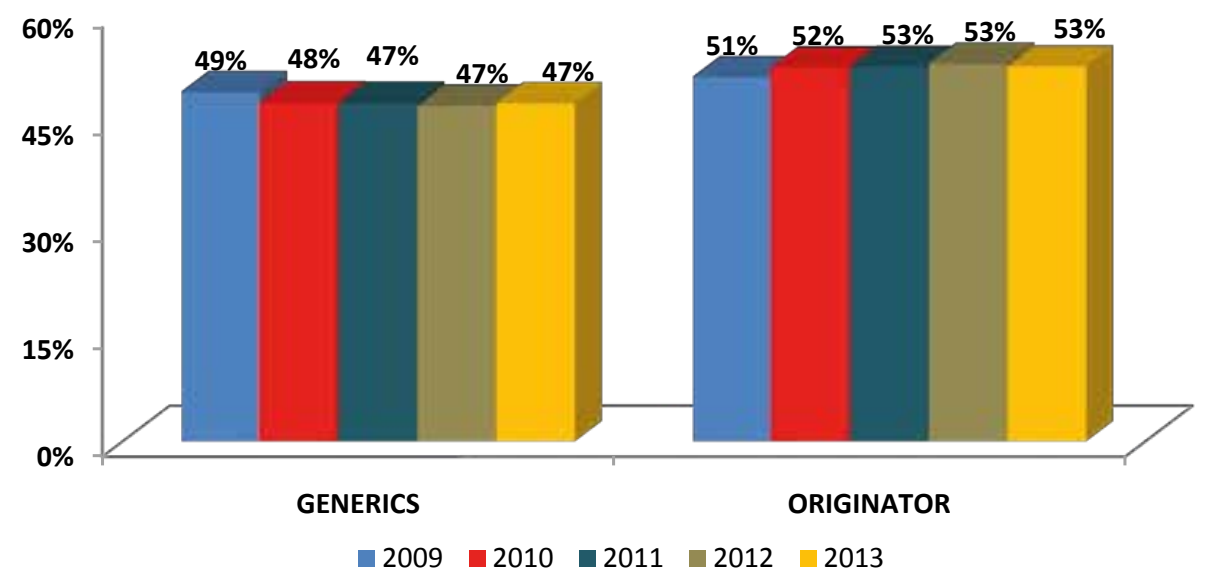

Figure 2: Generics and Originators Sales Value, 2009-2013

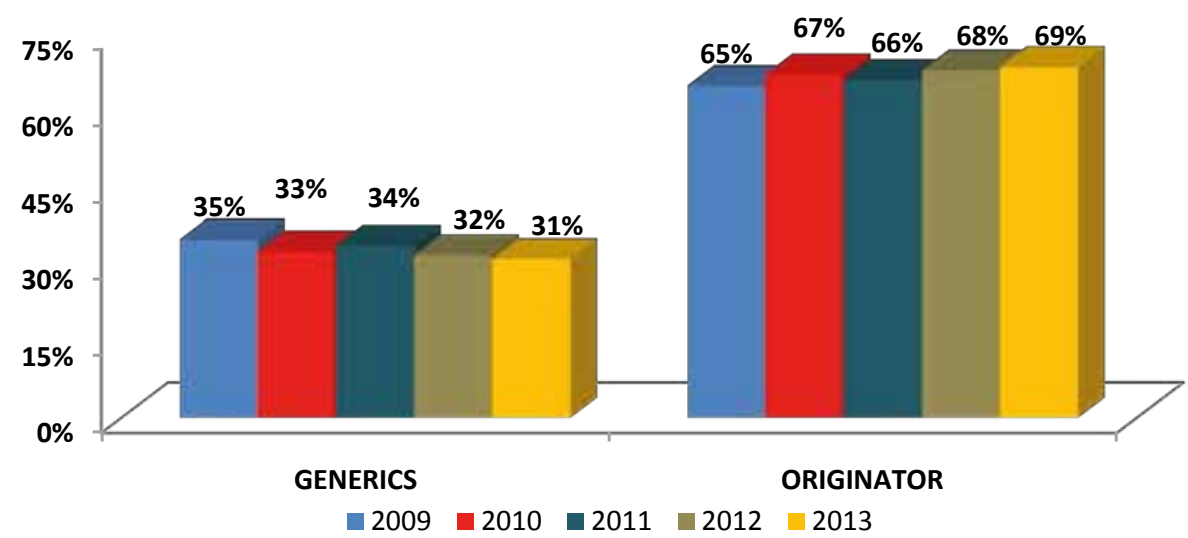


When it comes to the average discounted price (what is paid by SGK), while the average generic drug price dropped to $7.61 \mathrm{TL}$ in 2013 from 10.27 TL in 2009 ( $26 \%$ reduction), originators only shrank by $18 \%$ (reducing from $18.3 \mathrm{TL}$ to $15.1 \mathrm{TL}$ ) mostly due to cost-containment measures adopted since late 2009 such as increase in public rebates and reduction in the reference pricing of generics and their originators from $66 \%$ to $60 \%$. The main reason behind higher average price reduction in generics compared the originators stemmed from the fact that they were much more affected by those measures plus high-priced drugs entering the reimbursement list outweighed the price reduction in originators. When we ignore the drugs entering the reimbursement list in 2010 and onwards, average generic (originators) price in 2013 decreased to $6.6 \mathrm{TL}(14.3 \mathrm{TL})$. New generics (originators) penetrating the market 2010 and onwards had nearly $69 \%$ (36\%) higher average prices than the old ones entering the reimbursement list before 2010 . When we look at the newly reimbursed drugs after 2012, the results are different. On one hand new originators had 2.40 times higher prices; on the other hand new generics were only $48 \%$ expensive. This clearly shows that average prices for new drugs are on the rise in the recent years.

In Turkey, there are more than 1500 equivalent groups, generating roughly $64 \%$ of all sales value in 2013 . We can call those groups as unprotected market, since it is free to penetrate the market as soon as drugs are admitted to the reimbursement list. In the unprotected market, generics represented $50 \%$ of sales volume and only $45 \%$ of sales value, taking more share both in volume and value relative to the overall market. Utilization of generics within the unprotected market reached to $89 \%, 81 \%$, $75 \%, 73 \%, 71 \%, 65 \%, 59 \%$, and $52 \%$ in the US, Canada, Germany, Poland, UK, Brazil, Czech Republic, and France respectively (Sheppard, 2010), showing that Turkey is still lagging behind those countries and needs to implement new polices to promote generic utilization.

Among those equivalent groups, total sales value for selected 12 groups totaled $11 \%$ of sales value of unprotected market in 2013 , nearly $8 \%$ of overall sales value. Selected groups are denoted as Group A, B, C, D, E, F, G, H, I, J, K, and L. Average number of drugs in each group is 13 with a maximum and minimum of 26 and 3 respectively. Based on ATC classification system of WHO; 3, 1, 2, 4, 1, and 1 group/s belonged to the main ATC groups of alimentary tract and metabolism, blood and blood forming organs, cardiovascular system, anti-infective for systemic use, musculo-skeletal system, and antineoplastic and immunomodulating agents respectively.

In these groups, generics share in terms of sales volume rose from $50 \%$ in 2009 to $56 \%$ in 2013 . Over the same period, the highest increase in the generic share belonged to Group L and J with 49 and 33 percentage points respectively. However 
in Group $\mathrm{A}$ and $\mathrm{G}$ the share reduced by 11 and 7 percentage points. Group $\mathrm{L}$ and $\mathrm{H}$ (E and F) generated the highest (lowest) generic utilization. Regarding sales value, generics share rose from $44 \%$ in 2009 to $49 \%$ in 2013 .

Figure 3 shows how much generics in each group eroded prices and change in utilization over 2009 to 2013 . Prices eroded by $41 \%$ on average, generating 730 million TL worth of savings in 2013. In Group C price reduction reached to $74 \%$, the highest erosion, followed by Group $\mathrm{H}$ and I with 50\% reductions. In group C, 9 drugs offered additional public rebates to SGK due to fierce competition and that's why prices eroded significantly. In Group D and $G$ the erosion stayed too low, 3\% and $8 \%$ respectively, since the originator drug in each group was a 20 year old drug, meaning that generic entrance did not result in price change in their prices. In 17 developing countries, using lowest-priced generic equivalents instead of originators ended up $60 \%$ of cost savings (Cameron et al., 2012). Based on these analyses, it is difficult to conclude that the more the number of drugs in each group, the higher the price erosion. For instance, a group having 3 drugs achieved more reduction than a group of 19 drugs. Furthermore, higher generic utilization did not guarantee further lowering prices. Even though Group H and G made the highest generic utilization they could not generate the highest price reduction. Hence, Turkey could need to adopt new policies to further reduce prices.

As seen in Figure 3, sales volume growth over four years, from 2009 to 2013 , reached to $93 \%$, nearly $18 \%$ annually. In Group H, utilization skyrocketed and rose nearly sevenfold, followed by Group K and F. Utilization increase in Group C was also noteworthy, $30 \%$ annual growth.

Figure 3: Price Erosion and Sales Volume Growth Over 2009-2013

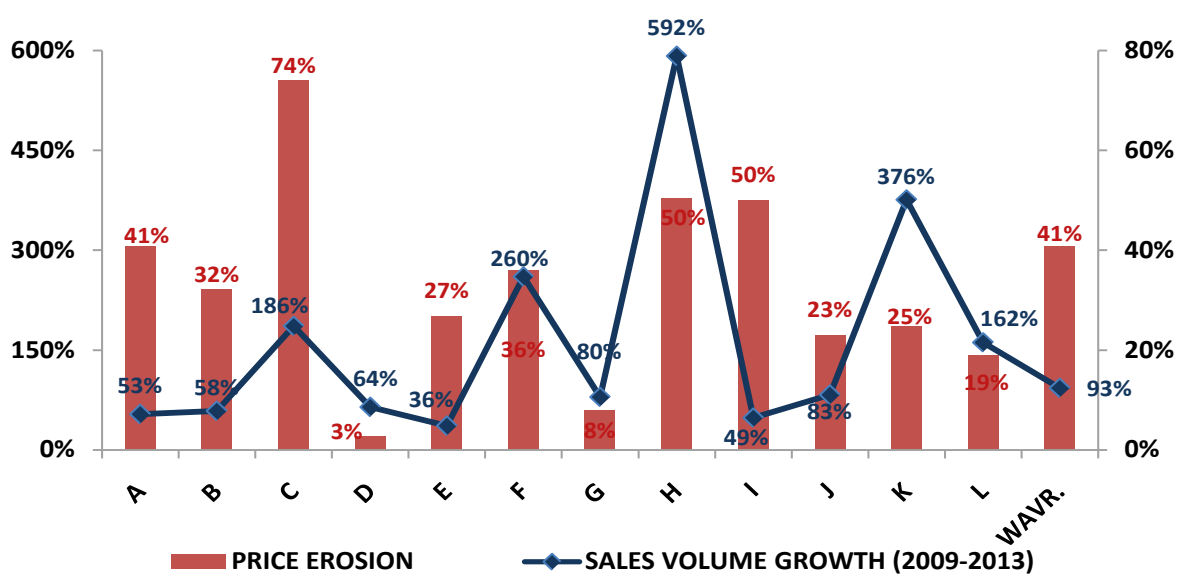


In Figure 4 weighted average discounted price in each group was compared to base price in the same group and the utilization rate for the base-priced drug was shown. Assuming that base price is 1.00 , only in three groups, namely Group E, I, and $\mathrm{K}$, the weighted average price was the same as base price, interestingly in Group A, C, and D the weighted average prices were so close to the $10 \%$ cap SGK pays. Those results imply that lowering the cap to the base price will end up savings for SGK. In Group E all drugs were priced at the base price; in Group K and I, 3 and 4 drugs constituted the base-priced drugs.

Figure 4: Weighted Average Price Among Equivalent Groups (Base Price=1.00)

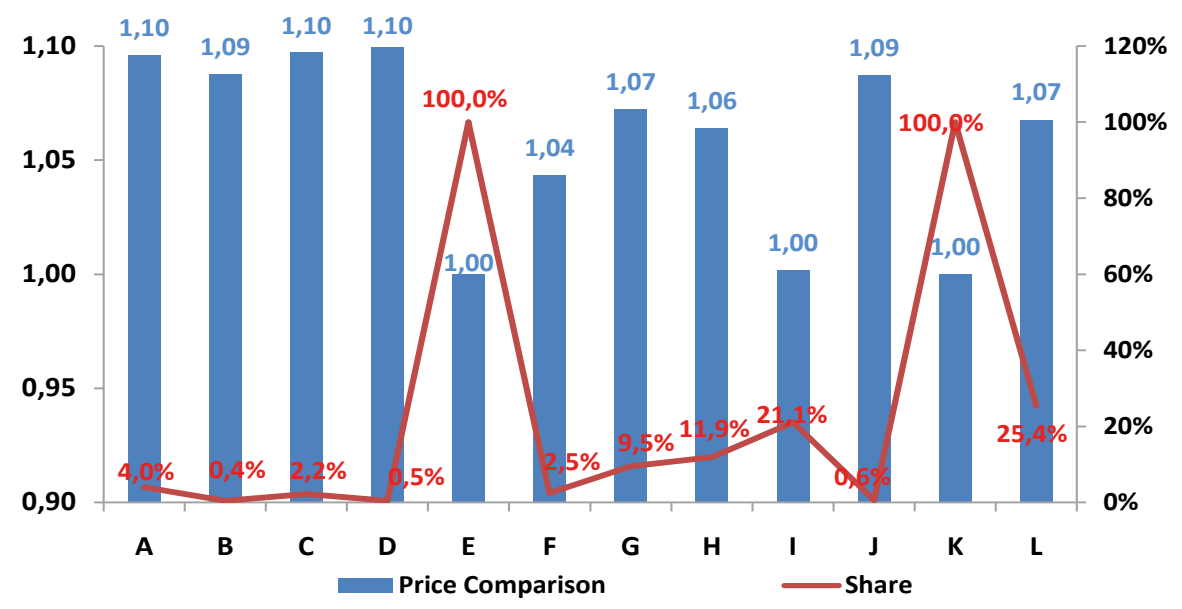

In 2012, 15 generics were added to the reimbursement list as first generics and constituted 15 different equivalent groups. 7, 3, 2, 2, and $1 \mathrm{drug} / \mathrm{s}$ were included in the main ATC groups of $\mathrm{L}, \mathrm{J}, \mathrm{V}, \mathrm{N}$, and $\mathrm{L}$ respectively. With first generic entry, reference price of the generic and originator drug reduced to $60 \%$ of lowest reference price of the originator in the $5 \mathrm{EU}$ countries. Turkey saved 133 billion TL due to first generic entry in 2013. Figure 5 explains how much prices went down and the evolution of sales volume growth over 2011 and 2013. Group names were denoted as Group K, L, M, N, O, P, R, S, T, U, V, W, X, Y, and Z. Weighted average price cut was calculated as $39 \%$. However, even though there were more than at least 3 generic drugs in the selected 10 equivalent groups among 12 groups the price erosion was only slightly higher, 2 percentage points, indicating that prices erode much with the first generic entry, then slight erosion with more and more generics penetrate. Therefore, pricing policy in Turkey does not encourage further price erosion as more and more generics enter the market, stating that Turkey is not maximizing the full benefit from generic utilization. The highest price erosion occurred in Group P and T 
by $62 \%$ and $57 \%$ respectively. The lowest figures belonged to Group $\mathrm{K}$ and $\mathrm{O}$ with $24 \%$. When looking at the sales volume growth numbers over two years, utilization improved by $41 \%$. In Group W utilization boosted by more than threefold. In Group $\mathrm{U}$ and $\mathrm{Z}$, even sales volume deteriorated. Utilization of generics in all groups in 2013 , right after the entry, came to $22 \%$ on average. Group U, O, and S took the highest shares with $60 \%, 59 \%$, and $56 \%$ respectively. The common feature of those groups is to have at least 2 generics. However, having more generics in a group did not assure more price reduction. Even though Group P, R, and T had the lowest generic utilization $(1 \%, 2 \%$, and $1 \%$ respectively), they enjoyed the highest price reduction.

As another analysis, the price reductions under 6 different wholesale prices with generic entry were assessed. The price reduction changed depending on the regressive wholesale and pharmacy margins, public rebates, and whether the originator is a 20 year old or not. As explained in the previous section the higher the wholesale price the more the rebates and rebates differ according to product group. A 20 year old originator drug price did not change when its generic entered the market, then no price reduction occurred. If not, the price erosion ranged between $19 \%$ and $28 \%$. As an example, an originator drug with the lowest reference price of $€ 165$ was paid for 252 TL by SGK. Provided its generic entered the market, SGK would only pay for $180 \mathrm{TL}$, a reduction of $29 \%$. Here, it means that generics erode prices at most $29 \%$ given no additional rebates offered, signaling a need for new policies to gain higher benefit from generics.

Figure 5: Price Erosion and Sales Volume Growth Over 2011-2013

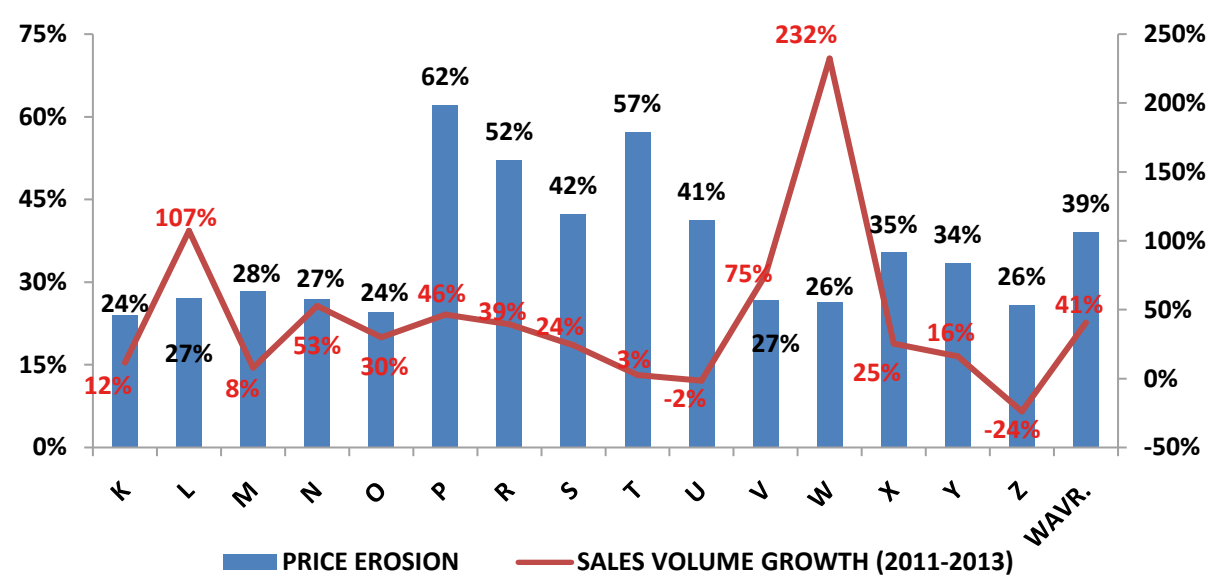




\section{Discussion and Alternative Policy Options}

In the light of all those analyses, it seems Turkey is not maximizing its full potential with respect to generics and generic pricing policies can be enhanced further. As a first alternative, SGK can reduce $10 \%$ cap to base price for all equivalent groups. This practice could at least save 470 billion TL yearly in 2014 prices. However, there are some risks associated for this policy change. It has to be bear in mind that as Turkish generic market is domestically dominant and Turkey is introducing incentives for domestic production, this policy can conflict with supporting domestic production. Moreover, reducing prices can lead to some drugs leaving the Turkish market and worsen competition.

Secondly, Turkey can shift to therapeutic equivalence from moleculebased equivalence for some groups. Germany and Holland have been using internal reference pricing system based on therapeutic equivalence for a long time (Galizzi et al., 2011; Danzon and Ketcham, 2004). With this implementation more and more drugs can merge under one group and prices can go down further. As an example, merging existing 8 equivalent groups into one therapeutic group and accepting the price cap as the average of three lowest discounted prices would reduce prices by $42 \%$ on average, 200 million TL saving annually for selected 12 equivalent groups.

Thirdly, Turkey can implement more aggressive generic pricing policy such as lowering $60 \%$ ( $80 \%$ for 20 year old drugs) reference pricing when two or more generics enter the market. According to a study conducted in the US, first generic price was slightly lower than the originator, but second generic dropped the average price by $50 \%$, and when larger number of generics penetrated the market, prices fell by $80 \%$ (IMS Health, 2005). As an option, in the case of each additional generic entry after the first generic, reference price for generics can be reduced by 10 percentage points till the price reaches $30 \%$ (50\% for 20 year old drugs) of reference price. Under this scenario, prices could further erode by $21 \%$ for 12 equivalent groups. In two of those groups, there occurred no reduction since there was only one generic.

Fourthly, countries such as Germany, Holland, Belgium, and Hungary have implemented tenders for ambulatory care drugs to constrain their pharmaceutical spending (Ferrario and Kanavos, 2013; Kanavos et al., 2009; Leopold et al., 2008). Tendering is a mechanism whereby purchaser buys drugs based on a competitive bidding process (Leopold et al., 2008). SGK can announce tenders for drugs having the same active molecule or therapeutic equivalence, further reducing prices and ensuring competition. However, tenders achieve savings in the short-run but their long-term results are uncertain (Leopold et al., 2008; Dylst et al., 2011). It is documented that tenders can lead to drug shortages, reduce investment, and induce 
monopoly supply positions (Sheppard, 2010; Simoens, 2013; Leopold et al., 2008; Dylst et al., 2011).

Lastly, many EU countries have been adopting risk sharing agreements to reduce spending, get rid of sales uncertainty, and evaluate the efficiency of the drugs in real-life experience (Ferrario and Kanavos, 2013; Carone et al., 2012; Adamski et al., 2010; Cook et al., 2008). Turkey can launch price-volume agreements for the equivalent group/s where utilization is expanding over the averages. For instance, in Group H, K, and F among 12 selected groups, price-volume agreements can work to stabilize spending.

\section{CONCLUSION}

Generics used as a substitute in place of original brand medicines are a good tool to mitigate drug spending and enhance access to medicines. Many countries are enjoying higher savings with generic utilization.

Turkey possesses a prominent branded generics market with domestic production. In 2013 generics represented $47 \%$ of sales volume and $31 \%$ of value, reducing 2 percentage points in volume and 4 points in value compared to 2009 . Relative to other EU countries the share of generics in value for Turkey is fairly higher, questioning whether they are eroding prices significantly.

Turkey seems not to maximize its full potential with respect to generic medicines. Among selected 12 equivalent groups, generics eroded prices by $41 \%$ and 15 first generics entering the reimbursement list 2012 reduced prices by $39 \%$. Therefore, to reduce prices further, hence generate additional savings, and in turn reimburse innovative high-cost drugs; generic policies can be enhanced further in Turkey. It is of great importance that policies such as lowering the cap to base price, moving from molecule-based internal reference pricing to therapeutic equivalence, implementing more aggressive pricing policies, launching tenders for outpatient drugs, and arranging price-volume agreements may be alternative options to be introduced by the policy makers. 


\section{REFERENCES}

Adamski, J., Godman, B., Ofierska-Sujkowska, G., Osińska, B., Herholz, H., Wendykowska, K., ... Gustafsson L. L. (2010). Risk sharing arrangements for pharmaceuticals: potential considerations and recommendations for European payers. BMC Health Services Research, 10(153), 1-16.

Cameron, A., Ewen, M., Ross-Degnan, D., Ball, D., \& Laing, R. (2009). Medicine prices, availability, and affordability in 36 developing and middle-income countries: a secondary analysis. Lancet, 373, 240-249.

Cameron, A., Mantel-Teeuwisse, A. K., Leufkens, H. G., \& Laing, R. O. (2012). Switching from originator brand medicines to generic equivalents in selected developing countries: How much could be saved. Value Health, 15(5), 664-673.

Carone, G., Schwiertz, C., \& Xavier, A. (2012). Cost-containment policies in public pharmaceutical spending in the EU. European Economy. Economic papers. Economic Papers 461. Brussels: European Union.

Cook, J. P., Vernon, J. A., \& Manning, R. (2008). Pharmaceutical risk-sharing agreements. Pharmaco Economics, 26(7), 551-556.

Danzon, M. P., \& Ketcham, J. D. (2004). Reference pricing of pharmaceuticals for Medicare: Evidence from Germany, the Netherlands, and New Zealand. Forum for Health Economics and Policy, 7, 1-47.

Dylst, P., Vulto, A., \& Simoens, S. (2011). Tendering for outpatient prescription pharmaceuticals: What can be learned from current practices in Europe? Health Policy, 101, 146-152.

FDA. (2015). FDA center for drug evaluation and research. Office of generic drugs. What are generic drugs? Retrieved from

http://www.fda.gov/Drugs/Resources ForYou/Consumers/ BuyingUsingMedicineSafely/UnderstandingGenericDrugs/ucm 144456.htm in August 15, 2016.

Ferrario, A., \& Kanavos P. (2013). Managed entry agreements for pharmaceuticals: The European experience. Brussels: Eminet.

Galizzi, M., Ghislandi, G., \& Miraldo, M. (2011). Effects of reference pricing in pharmaceutical markets. Pharmaco Economics, 29(1), 17-33. 
Generic Pharmaceutical Association. (2015). Generic Drugs Savings in the US Report 2015. Seventh Annual Edition:2015. Retrieved from http://www.gphaonline. org/media/wysiwyg/PDF/GPhA_Savings_Report_2015.pdf .

Godman, B., Shrank, W., Wettermark, B., Andersen, M., Bishop, I., Burkhardt, T., ... Gustafsson, L. L. (2010). Use of generics - a critical cost containment measure for all healthcare professionals in Europe. Pharmaceuticals, 3, 2470-2494.

Godman, B., Wettermark, B., Bishop, I., Burkhardt, T., Fürst, J., Garuoliene, K., ... Gustafsson, L. L. (2012). European payer initiatives to reduce prescribing costs through use of generics. Generics and Biosimilars Initiative Journal, 1, 22-27.

IMS Health. (2005). IMS National Sales Perspective (TM), 1999-2004, extracted February 2005. Retrieved from http://www.fda.gov/AboutFDA/CentersOffices/ OfficeofMedicalProductsandTobacco/CDER/ucm129385.htm in September 21, 2016.

Kanavos, P., Seeley, L., \& Vandoros, S. (2009). Tender systems for outpatient pharmaceuticals in the European Union: Evidence form Netherlands, Germany and Belgium. Brussels: European Commission.

Leopold, C., Habl, C., \& Vogler, S. (2008). Tendering of pharmaceuticals in EU member states and EEA countries. Results from the country survey. Retrieved from

http://whocc.goeg.at/Literaturliste/Dokumente/BooksReports/Final_Report_ Tendering_June_08.pdf .

MOH. (2015). Notification on the pricing of medicinal products for human use. Retrieved from http://www.resmigazete.gov.tr/eskiler/2015/12/20151211-3.htm in June 15, 2016.

Seeley, E., \& Kanavos, P. (2008). Generic medicines from a societal perspective: Savings for health care systems? Eurohealth, 14(2), 18-22.

Sermet, C., Andrieu,V., Godman B., Van Ganse, E., Haycox, A., \& Reynier, J. P. (2010). Ongoing pharmaceutical reforms in France: implications for key stakeholder groups. Applied Health Economics and Health Policy, 8(1), 7-24.

SGK. (2016a). Regulation on Drug Reimbursement. Retrieved from http://www. resmigazete.gov.tr/eskiler/2016/02/20160210-7.htm in August 13, 2016.

SGK. (2016b). Health implementation practice. Retrieved from http://www. saglikaktuel.com/mwg-internal/de5fs23hu73ds/progress?id=sQRhI-ssJ1gQo6DBC c8xvP3DoRIsum3YvR9U8ExxShI in September 20, 2016. 
Sheppard, A. (2010). Generic medicines: Essential contributors to long-term health of society. Retrieved from http://www.medicinesforeurope.com/ wpcontent/uploads /2016/03/IMS_Generic_Medicines_Essential_contributors.pdf .

Simoens, S. (2012). A review of generic medicines pricing in Europe. Generics and Biosimilars. Initiative Journal, 1, 8-12.

Simoens, S., \& De Coster, S. D. (2006). Sustaining generic medicines market in Europe. Journal of Generic Medicines, 3, 257-268.

Simoens, S. (2013). Sustainable provision of generic medicines in Europe. Retrieved from http://www.generikusegyesulet.hu/mwginternal/de5fs23hu73ds/ progress?id=EiS+Vact7.

TITCK. (2005). Registration regulation of human medicinal products. Retrieved from http://www.titck.gov.tr/PortalAdmin/Uploads/UnitPageAttachment/459e11 9d86725.pdf in August 30, 2016.

Tootelian, D. H., Gaedeke, R. M., \& Schlacter, J. (1988). Branded Versus Generic Prescription Drugs: Perceptions of Risk, Efficacy, Safety, and Value. Journal of Health Care Marketing, 8(3), 26-29.

Vogler, S. (2012). How large are the differences between originator and generic prices? Analysis of five molecules in sixteen European countries. Farmeconomia. Health economics and therapeutic pathways, 13, 29-41.

WHO. (1988). How to develop and implement a national drug policy. Retrieved from http://apps.who.int/medicinedocs/pdf/s2283e/s2283e.pdf.

WHO. (1988). Guidelines for developing national drug policies. Geneva: World Health Organization.

WHO. (1996). WHO Expert Committee on Specifications for Pharmaceutical Preparations. Thirty-fourth Report. WHO Technical Report Series No.863, Annex 9. Multisource (generic) pharmaceutical products: guidelines on registration requirements to establish interchangeability. Geneva: World Health Organization.

WHO. (1998). Marketing authorization of pharmaceutical products with special reference to multisource (generic) products. A manual for a drug regulatory authority. Regulatory Support Series No.5. Geneva: World Health Organization. 